\title{
Analisis Strategi Pemecahan Masalah Matematika Siswa SMP Ditinjau dari Kemampuan Matematika
}

\author{
Renata Nurlaily Rowdlotul Jannah ${ }^{1}$, Pradnyo Wijayanti ${ }^{2}$ \\ ${ }^{1,2}$ Program Studi Pendidikan Matematika, FMIPA, Universitas Negeri Surabaya, \\ Jl. Ketintang, Surabaya, Indonesia \\ Email penulis pertama: renata.17030174048@mhs.unesa.ac.id
}

\begin{abstract}
Problem solving strategy is a technique or problem-solving method used in finding solutions. Differences in mathematical ability can affect students in applying and sorting out problem-solving strategies. This type of research is descriptive research with a qualitative approach that aims to describe the mathematics problem-solving strategies of junior high school students in terms of mathematical abilities. Data collection was carried out by means of a test of mathematical ability and mathematical problem-solving tasks, followed by interviews. The subjects in this study were students with high, medium, and low mathematical abilities, one each. Data analysis used is data reduction, data presentation, and data retrieval. The results obtained are students who have high mathematical abilities using problem-solving strategies logical reasioning, guess and check, adopting a different point of view, using extreme conditions, accounting for all possibilities, and organizing data, while students who have moderate mathematical abilities use test problem-solving strategies guess and check, walking backwards, using extreme conditions and accounting for all possibilities, and students who have low math ability use problem-solving strategies guess and check, using extreme conditions, and logical reasoning.
\end{abstract}

Keywords: Problem Solving Strategies, Problem Solving, Math Problem, Math Skills

\begin{abstract}
Abstrak
Strategi pemecahan masalah adalah suatu teknik atau cara penyelesaian masalah yang digunakan dalam mencari solusi. Perbedaan kemampuan matematika dapat mempengaruhi siswa dalam menerapkan dan memilah strategi pemecahan masalah. Jenis penelitian ini adalah penelitian deskriptif dengan pendekatan kualitatif yang bertujuan untuk mendeskripsikan strategi pemecahan masalah matematika siswa SMP ditinjau dari kemampuan matematika. Pengumpulan data dilakukan dengan tes kemampuan matematika dan tugas pemecahan masalah matematika kemudian dilanjutkan dengan wawancara. Subjek dalam penelitian ini yakni siswa memiliki kemampuan matematika tinggi, sedang dan rendah masing-masing satu. Analisis data yang digunakan adalah reduksi data, penyajian data, dan penarikan data. Hasil yang diperoleh adalah siswa yang memiliki kemampuan matematika tinggi menggunakan strategi pemecahan masalah penalaran logis, uji coba, menggubah cara pandang terhadap masalah, menggunakan keadaan yang ekstrim, mempertimbangkan segala kemungkinan dan mengorganisir data, sedangkan siswa yang memiliki kemampuan matematika sedang menggunakan strategi pemecahan masalah uji coba, berjalan mundur, menggunakan keadaan yang ekstrim dan mempertimbangkan segala kemungkinan, dan siswa yang memiliki kemampuan matematika rendah menggunakan strategi pemecahan masalah uji coba, menggunakan keadaan yang ekstrim, dan penalaran logis.
\end{abstract}

Kata kunci: Strategi Pemecahan Masalah, Pemecahan Masalah, Masalah Matematika, Kemampuan Matematika

Copyright (c) 2021 Renata Nurlaily Rowdlotul Jannah, Pradnyo Wijayanti

$\square$ Corresponding author: Renata Nurlaily Rowdlotul Jannah

Email Address: renata.17030174048@mhs.unesa.ac.id (Jl. Ketintang, Surabaya, Indonesia)

Received 28 June 2021, Accepted 15 July 2021, Published 06 September 2021

\section{PENDAHULUAN}

Kemampuan pemecahan masalah merupakan salah satu kemampuan yang mendasar dan harus dipenuhi (Suyanto, 2013). Hal ini berarti siswa harus menguasahi kemampuan pemecahan masalah terlebih dahulu untuk dapat meningkatkan kemampuan berpikir tingkat tinggi seperti kemampuan berfikir kreatif dan kemampuan berfikir kritis. Seperti yang diungkapkan oleh Afgani (2011)bahwa pembelajaran matematika akan lebih bermakna jika dalam pembelajaran terdapat pemahaman, penalaran, komunikasi, koneksi, pemecahan masalah, dan representasi yang merupakan standar 
pemelajaran dalam matematika. Jadi, siswa akan merasakan makna matematika melalui pemecahan masalah.

Namun hingga saat ini masih banyak terjadi guru mengalami kesulitan dalam mengajarkan pemecahan masalah di kelas sehingga siswa juga kesulitan dalam mempelajari dan menyelesaikannya. Kesulitan ini disebabkan karena dalam menyelesaikan masalah belum menggunakan strategi pemecahan masalah, namun mereka hanya belajar menyelesaikan masalah dengan rumus. Hal ini diperkuat oleh Andinasari et al., (2019) yang menyatakan bahwa siswa dicegah merespon serta menyelesaikan permasalahan matematika disebabkan mereka terbiasa berpikir secara prosedural. Aydogdu \& Kesan (2014) menyatakan bahwa salah satu faktor penting dalam pemecahan masalah adalah cara memilih dan menerapkan strategi pemecahan masalah.

Seseorang siswa memerlukan strategi penyelesaian dari masalah tersebut dalam menyelesasikan pemecahan masalah. Strategi pemecahan masalah adalah metode atau tahapan bekerja yang digunakan seseorang dalam menyelesaikan pemecahan masalah yang independen dari topik tertentu (Ayuningrum, 2017). Hal ini berarti dalam menyelesaikan pemecahan masalah dituntut kemampuan siswa menerapkan dan memilah strategi dengan tepat dan benar, menggunakan pengetahuan serta pengalaman memecahkan masalah sebelumnya. Ada 10 strategi pemecahan masalah dalam menyelesaiakan permasalahan (Posamentier \& Krulik, 2008). Menurut Dinata (2017) Srategi pemecahan masalah merupakan tahapan berpikir yang digunakan ketika akan memecahkan suatu masalah. Pemecahan suatu masalah dengan karakteristik tertentu yang dapat ditempuh dengan satu strategi pemecahan masalah, namun terdapat pemecahan masalah yang dapat ditempuh dengan berbagai macam strategi pemecahan masalah. Namun yang menjadi persoalan adalah cara menentukan strategi pemecahan yang terbaik dan terefisien dalam memecahkan masalah karena dalam hal ini mengarah pada pengalaman dan pengetahuan yang telah dimiliki siswa.

Kemampuan untuk menyelesaikan masalah matematika dipengaruhi oleh banyak faktor, salah satunya adalah perbedaan individu. Seperti yang diungkapkan oleh Aydogdu \& Kesan (2014) bahwa dalam menyelesaikan pemecahan masalah, seseorang menggunakan strategi pemecahan masalah yang berbeda-beda bergantung pada pengalaman atau penguasaan konsep matematika yang telah dimiliki. Hal ini berarti perbedaan kemampuan matematika seseorang bergantung pada penguasaan konsep setiap individadan kemampuan pemecahan masalah. Pernyataan di atas didukung oleh penelitian yang dilakukan Asmiati (2014), terdapat perbedaan signifikan pada waktu dan strategi dalam memecahkan masalah. Siswa dengan gaya reflektif lebih membutuhkan waktu dalam menyelesaikan masalah dan menggunakan strategi membuat gambar. Sedangkan subjek implusif membutuhkan waktu lebih cepet dalam memecahkan masalah dan menggunakan strategi mendata semua kemungkinan jawaban. Hal ini menunjukkan bahwa perbedaan individu berpengaruh pada pemilihan strategi yang digunakan siswa dalam memecahkan masalah. Dalam penelitian tersebut hanya menjelaskan 6 strategi pemecahan masalah belum ke-sepuluh strategi pemecahan masalah. Berdasarkan uraian tersebut, penelitian ini berjudul "Analisis Strategi Pemecahan Masalah Matematika Siswa SMP Ditinjau dari Kemampuan 
Matematika". Penelitian ini bertujuan untuk mendeskripsikan strategi pemecahan masalah matematika siswa SMP ditinjau dari kemampuan matematika.

\section{METODE}

Penelitian ini merupakan penelitian deskriptif dengan menggunakan pendekatan kualitatif, yaitu gambaran dan analisis secara keseluruhan penggunaan strategi-strategi yang digunakan siswa dalam menyelesaikan pemecahan masalah matematika. Penelitian ini dilaksanakan di kelas VIII F SMP Negeri 1 Grogol tahun ajaran 2020/2021. Pada tahap pelaksanaan, penentuan subjek dilakukan dengan memberikan tes kemampuan matematika kepada siswa kelas VIII F secara online melalui Google Classroom. Tes kemampuan matematika terdiri dari 10 soal uraian dengan materi kelas7 dengan waktu pekerjaan 90 menit. Berdasarkan hasil tes kemampuan matematika siswa, peneliti mengambil 3 subjek yang terdiri masing-masing satu siswa dengan kemampuan matematika tinggi, sedang dan rendah. Berikut adalah katagori kemampuan matematika siswa.

Tabel 1. Kategori Kemampuan Matematika

\begin{tabular}{|c|c|}
\hline Skor & Kategori \\
\hline $85 \leq \mathrm{x} \leq 100$ & Tinggi \\
\hline $85<\mathrm{x} \leq 75$ & Sedang \\
\hline $\mathrm{x}<75$ & Rendah \\
\hline
\end{tabular}

Setelah 3 subjek terpilih maka diberikan tugas pemecahan masalah matematika guna pemgambilan data. Tugas ini dilakukan untuk mengetahui strategi yang digunakan siswa dalam memecahkan masalah matematika. Kemudian setelah diperoleh data penelitian, peneliti melakukan wawancara guna memperjelas dan melengkapi informasi yang kurang jelas secara lisan. Wawancara ini telah disesuaikan dengan hasil tugas pemecahan masalah. Hasil tugas pemecahan masalah matematika akan dianalisis menggunakan 10 strategi pemecahan masalah agar mendapatkan gambaran strategi pemecahan masalah siswa dalam menyelesaikan masalah matematika. Berikut indikator strategi pemecahan masalah dalam pembelajaran matematika.

Tabel 2. Indikator Strategi pemecahan masalah

\begin{tabular}{|l|l|l|}
\hline No & \multicolumn{1}{|c|}{$\begin{array}{c}\text { Strategi Pemecahan } \\
\text { Masalah }\end{array}$} & \multicolumn{1}{c|}{ Indikator } \\
\hline 1. & Berjalan mundur & $\begin{array}{l}\text { - Menyelesaikan permasalahan dimulai dengan hasil akhir. } \\
\text { - Bergerak mundur untuk menentukan keadaan awal. }\end{array}$ \\
\hline 2. & Menentukan pola & $\begin{array}{l}\text { - Menganalisis dan mengaitkan hal yang diketahui dalam } \\
\text { masalah untuk membentuk konsep matematika. }\end{array}$ \\
\hline 3. & $\begin{array}{l}\text { Mengubah cara pandang } \\
\text { terhadap masalah }\end{array}$ & $\begin{array}{l}\text { - Menemukan keteraturan atau pola. } \\
\text { - Menemukan sudut pandang dalam menyelesaikan masalah. }\end{array}$ \\
\hline 4. & $\begin{array}{l}\text { Membuat analogi } \\
\text { sederhana }\end{array}$ & $\begin{array}{l}\text { - Mengubah masalah yang diberikan menjadi setara. } \\
\text { menyederhanakan angka yang diberikan. }\end{array}$ \\
\hline 5. & $\begin{array}{l}\text { Menggunakan keadaan } \\
\text { yang ekstrim }\end{array}$ & $\begin{array}{l}\text { - Mengasumsikan suatu masalah dalam keadaan paling } \\
\text { ekstrim (jika perlu mengghilangkan keadaan tersebut). }\end{array}$ \\
\hline
\end{tabular}




\begin{tabular}{|c|c|c|}
\hline 6. & Membuat gambar & $\begin{array}{l}\text { - Menganalisis hubungan antara apa yang diketahui dan } \\
\text { ditanyakan. } \\
\text { - Membuat representasi visual. }\end{array}$ \\
\hline 7. & Uji coba & $\begin{array}{l}\text { - Melakukan coba-coba. } \\
\text { - Membuat kesimpulan dengan benar. }\end{array}$ \\
\hline 8. & $\begin{array}{l}\text { Mempertimbangkan segala } \\
\text { kemungkinan }\end{array}$ & - Membuat semua kemungkinan jawaban. \\
\hline 9. & Mengorganisir data & $\begin{array}{l}\text { - Mengolah dan mengorganisir data dengan membuat daftar } \\
\text { atau tabel. } \\
\text { - Membuat kesimpulan dengan benar. }\end{array}$ \\
\hline 10. & Penalaran Logis & $\begin{array}{l}\text { - Menganalisis hubungan antara yang diketahui dan } \\
\text { ditanyakan. } \\
\text { - Membuat informasi baru berdasarkan hasil analisis. }\end{array}$ \\
\hline
\end{tabular}

(Posamentier \& Krulik, 2008)

Hasil validasi menunjukkan bahwa ketiga instrumen tersebut valid. Pada tahap akhir yaitu analisis data, teknik analisis data yang digunakan adalah analisis deskriptif kualitatif dengan menggunakan tahapan analisis (Sugiyono, 2019) yang terdiri dari reduksi data, penyajian data, dan penarikan data atau verifikasi.

\section{HASIL DAN DISKUSI}

\section{Hasil}

Berdasarkan hasil tes kemampuan matematika, siswa yang terpilih manjadi subjek penelitian adalah satu siswa yang memiliki kemampuan matematika tinggi (ST), satu siswa yang memiliki kemampuan matematika sedang (SS), dan satu siswa yang memilliki kemampuan matematika rendah (SR). Berikut hasil pemecahan masalah matematika siswa yang telah dianalisis berdasarkan 10 strategi pemecahan masalah matematika.

\section{Siswa dengan Kemampuan Matematika Tinggi (ST)}

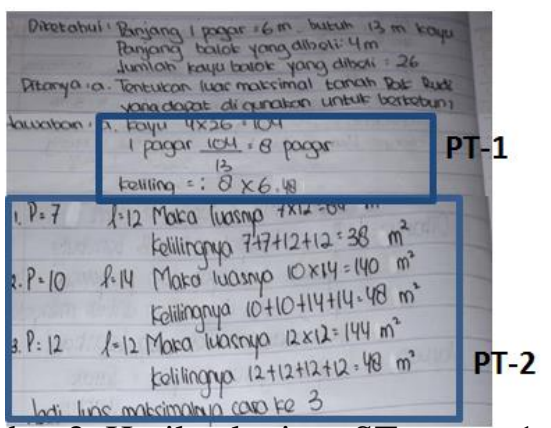

Gambar 2. Hasil pekerjaan ST nomor 1

Berikut disajikan hasil wawancara untuk menggali informasi lebih lanjut terhadap hasil pekerjaan ST.

Peneliti : Coba jelaskan bagaimana memperoleh keliling sama dengan 48!

ST01 : Saya mencari panjang keseluruhan balok kayu terlebih dahulu, yaitu $104 \mathrm{~m}$. Kemudaian saya mencari banyak pagar yang dapat terbentuk dengan panjang keseluruhan 104 m, maka diperoleh 8 pagar. Karena diketahui jika panjang satu pagar adalah 6 maka panjang pagar keseluruhan adalah $6 \times 8=48$. 
Peneliti : Jelaskan bagaimana kamu mengetahui jika luas maksimumnya adalah $144 m^{2}$ ?

ST02 : Saya melakukan cara mencoba-coba bu.

Peneliti : Bagaimana kamu menggunakan cara mencoba-coba?

ST03 : Dengan mengubah panjang dan lebarnya bu,namun dengan kelilingnya adalah $48 \mathrm{~m}$. Jika p= 7 dan l=12, maka ditemukan keliling dan luas adalah $38 \mathrm{~m}$ dan $84 \mathrm{~m}^{2}$. Kemudian saya naikkan nilai $p$ dan l menjadi $p=10$ dan l=14, maka keliling dan luasnya adalah $48 \mathrm{~m}$ dan $140 \mathrm{~m}^{2}$. Kemudian saya naikkan lagi menjadi $p=12$ dan l=12, maka keliling dan luasnya adalah $48 \mathrm{~m}$ dan $144 m^{2}$. Maka luas maksimumnya adalah $144 m^{2}$, karena jika nilai panjang dan lebarnya dinaikkan, luasnya menjadi lebih kecil.

Berdasarkan hasil pekerjaan dan wawancara terhadap soal nomor 1, ST telah memahami masalah. Kemudian ST mampu menganalisis hubungan antara yang diketahui dan ditanyakan, dengan mencari panjang keseluruhan kayu terlebih dahulu (ST01). ST juga mampu menemukan informasi baru berdasarkan hasil analisis yaitu banyak pagar yang dapat dibuat dari panjang kayu tersebut (PT-1 dan ST01). Sehingga, ST memenuhi indikator strategi pemikiran logis. Selanjutnya dalam menentukan luas maksimum tanah, ST mencoba-coba dengan mengubah panjang dan lebarnya (PT-2, ST02, dan ST03). ST juga menuliskan kesimpulan bahwa luas lahan maksimal yaitu $144 \mathrm{~m}^{2}(\mathbf{P T}-2)$. Hal ini menunjukkan jika ST juga menggunakan indikator strategi pemecahan masalah uji coba. Kemudian pada pekerjaan nomor 2, ST menjawab permasalahan dengan benar dan memberikan penjelasan yang mendukung pekerjaannya.

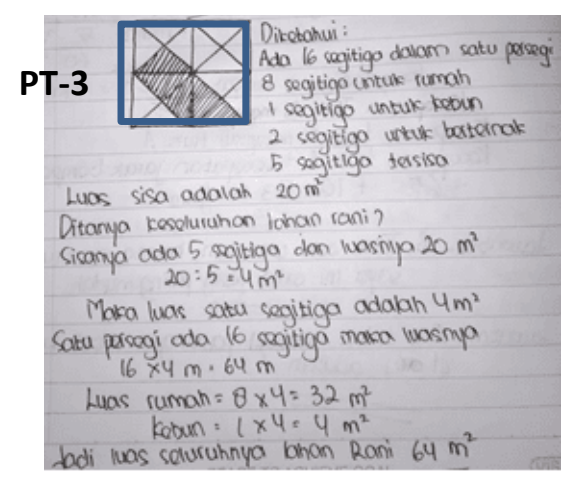

Gambar 3. Hasil pegerjaan siswa ST nomor 2

Berikut hasil wawancara untuk menggali informasi lebih lanjut terhadap hasil pekerjaan ST.

Peneliti : Apakah kamu paham mengenai permasalahan tersebut?

ST04 :Paham bu.

Peneliti : Bagaimana kamu mengubah informasi tersebut menjadi 16 segitiga?

ST05 : Diketahui bahwa bentuk lahannya persegi bu, jadi saya menggambar persegi terlebih dahulu, kemudian ada segitiga besar dan kecil di dalam persegi berdasarkan soal, maka saya menjadikannya segitiga kecil yang sama besar bu dan ada 16 segitiga kecil sama besar. 
Berdasarkan hasil pekerjaan dan wawancara terhadap soal nomor 2, ST telah memahami masalah, hal ini ditunjukkan melalui hasil wawancara ST (ST04). Kemudian ST mampu mengubah sudut pandang terhadap masalah dengan menggunakan garis bantuan untuk membuat segitiga sama besar berjumlah 16 untuk menyelesaikan masalah (PT-3 dan ST05). ST juga mampu menemukan konsep matematika yang efektif dengan mencari luas satu segitiga untuk menentukan luas keseluruhan lahan. Sehingga ST memenuhi indikator strategi pemecahan masalah mengubah cara pandang terhadap masalah. Selanjutnya pada pekerjaan soal nomor 3, ST telah menjawab permasalahan dengan benar serta memberikan penjelasan yang mendukung pengerjaaannya.

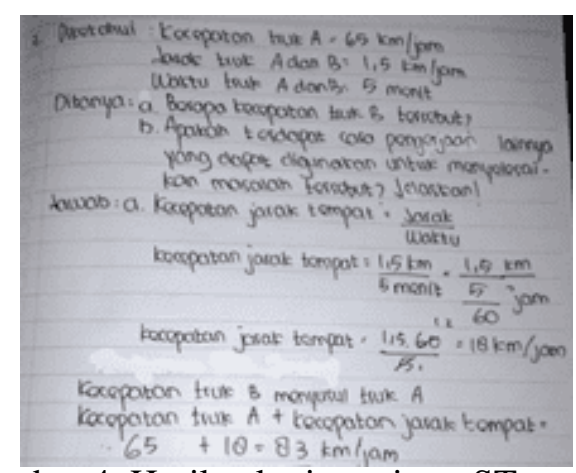

Gambar 4. Hasil pekerjaan siswa ST nomor 3

Berikut hasil wawancara untuk menggali informasi lebih lanjut terhadap hasil pekerjaan ST.

Peneliti : Bagaimana menurutmu mengenai informasi bahwa truk A bergerak dengan kecepatan tetap $65 \mathrm{~km} / \mathrm{jam}$ ?

ST06 : Saya anggap 0 bu, karena kecepatannya tetap jadi tisak saya cantumkan.

Bersadarkan pekerjaan dan wawancara pada nomor 3, ST telah memahami masalah. Selanjutnya ST mampu mengasumsikan suatu masalah dalam keadaan paling ekstrim (jika perlu menggilangkan keadaan tersebut), dimana ST mengasumsikan jika truk A yang bergerak tetap maka kecepatan truk A adalah 0 km/jam (ST06). Hal tersebut menunjukkan bahwa ST memenuhi indikator strategi pemecahan masalah menggunakan keadaan yang ekstrim dalam menyelesaikan masalah. Selanjutnya pada pekerjaan soal nomor 4, ST telah menjawab permasalahan dengan benar serta memberikan penjelasan yang mendukung pengerjaaannya.

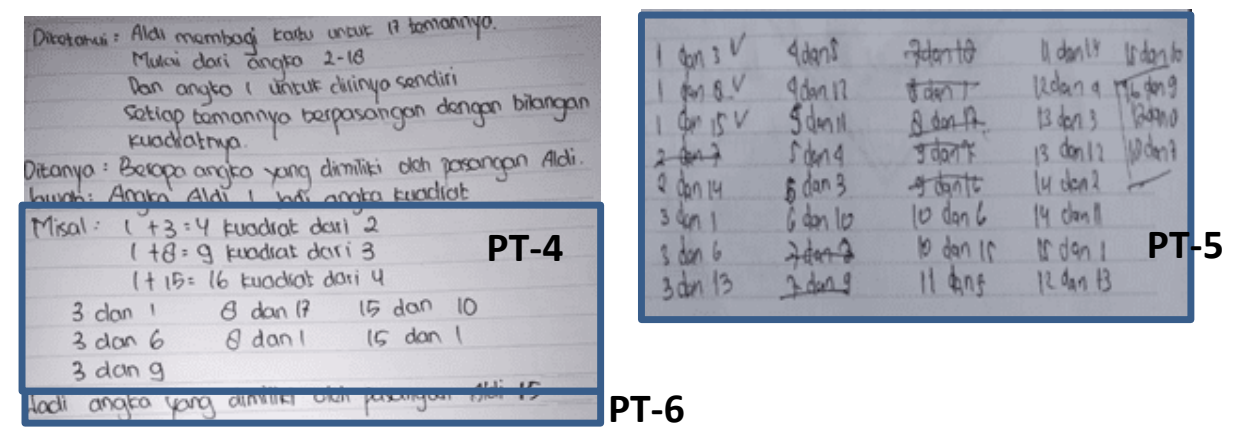

Gambar 5. Hasil pekerjaan siswa ST nomor 4

Berikut hasil wawancara untuk menggali informasi lebih lanjut terhadap hasil pekerjaan ST. 
Peneliti : Coba kamu jelaskan bagaimana memperoleh hasil jika angka pasangan aldi adalah 15?

ST07 : Awalnya saya menuliskan angka yang jika dijumlahkan dengan 1 hasilnya kuadrat bu, yaitu 3, 8, dan 15. Kemudian saya membuat semua kemungkinan yang jumlahnya kuadarat. Dari daftar tersebut diketahui bahwa 16, 17, dan 18 hanya memiliki satu pasangan yang membentuk kuadrat yaitu 9, 8, dan 7. Kemudian saya hilangkan angka yang berkaitan dengan 7, 8, 9,16, 17, dan 18. Saya hilangkan lagi angka-angka yang saling berkebalikan. Kemudian saya coba awalya dengan menghilangkan angka 3, karena pasangan 3 ada 6 dan 13, itu saya hilangkan semua. Akhirnya tersisa 1 dan 15, 2 dan 14, 3 dan 13, 4 dan 12, 5 dan 11, 6 dan 10, 7 dan 18,8 dan 17, dan 9 dan 16.

Peneliti : Mengapa kamu tidak menghilangkan angka 15 terlebih dahulu?

ST08 : Karena saya mencoba terlebih dahulu angka 3 yang saya hilangkan dan sudah ketemu hasilnya bu.

Bersadarkan pekerjaan dan wawancara pada nomor 4, ST telah memahami masalah. Selanjutnya ST mampu membuat semua kemungkinan jawaban dengan menuliskan semua kemungkinan pasangan satu adalah 3, 8, dan 15 (PT-4 dan ST08). Ini berarti ST telah memenuhi indikator strategi pemecahan masalah mempertimbangkan segala kemungkinan. Selanjutnya ST mampu mengorganisir data dengan membuat daftar pasangan-pasangan bilangan kuadrat untuk memudahkan mengeliminasi pasangan bilangan (PT-5). ST juga mampu menuliskan kesimpulan dengan benar (PT-6). Hal ini berarti ST telah memenuhi indikator strategi pemecahan masalah mengorganisir data. Kemudian ST juga memenuhi indikator strategi pemecahan uji coba. Hal ini dibukitkan dengan ST mampu mengeleminasi pasangan dengan cara mencoba-coba (ST08) dan menarik kesimpulan dengan benar (PT-6).

\section{Siswa dengan Kemampuan Matematika Sedang (SS)}

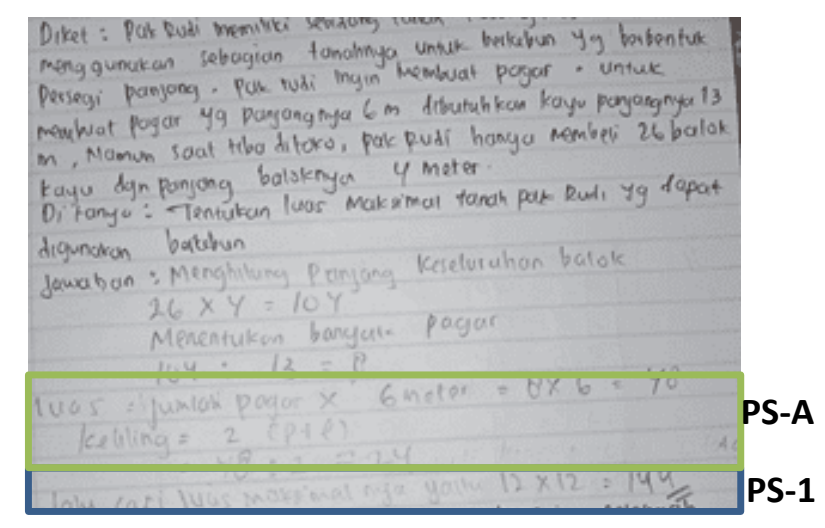

Gambar 6. Hasil pekerjaan SS nomor 1

Berikut hasil wawancara untuk menggali informasi lebih lanjut terhadap hasil pekerjaan SS.

Peneliti : Apakah luas dan kelilingnya sama besar?

SS01 : Iya ya bu, saya menjadi bingung. Oh, begini bu sebenarnya luas itu adalah panjang pagar semuanya. Jadi nanti sama dengan kelilingnya.

Peneliti : Kemudian bagaimana kamu mengetahui jika luas maksimumnya adalah $144 \mathrm{~m}^{2}$ ? 
SSO2 : Saya mencari panjang dan lebarnya yang berjumlah 24, kemudian saya membuat data yang panjang dan lebarnya mulai 1 sampai 23, lalu saya coba satu-satu. Ditemukan jika luas maksimumnya adalah $144 \mathrm{~m}^{2}$.

Bersadarkan hasil pekerjaan dan wawancara terhadap soal nomor 1, SS kurang memahami masalah. Hal ini ditunjukkan dengan kurang mampu SS dalam menghubungkan informasi (PS-A). Tidak adanya informasi mengenasi hasil keliling yang dituliskan, namun SS menuliskan jika kelilingnya adalah 48. SS juga menuliskan jika luasnya adalah 48, namun tidak disertakan luas apakah itu dan SS tidak dapat menjelaskan dalam proses wawancara. Kemudian bahwa SS dalam menentukan luas maksimum membuat coretan di kertas lain, SS mencoba satu-satu hingga ditemukan panjang dan lebarnya adalah $12 \mathrm{~cm}$ dan hasilnya adalah $144 \mathrm{~m}^{2}$ (PS-1 dan SS02). Hal ini berarti SS telah memenuhi strategi pemecahan masalah uji-coba dalam menentukan luas maksimum lahan. Kemudian pada pekerjaan nomor 2, SS menjawab permasalahan dengan benar dan memberikan penjelasan yang mendukung pekerjaannya

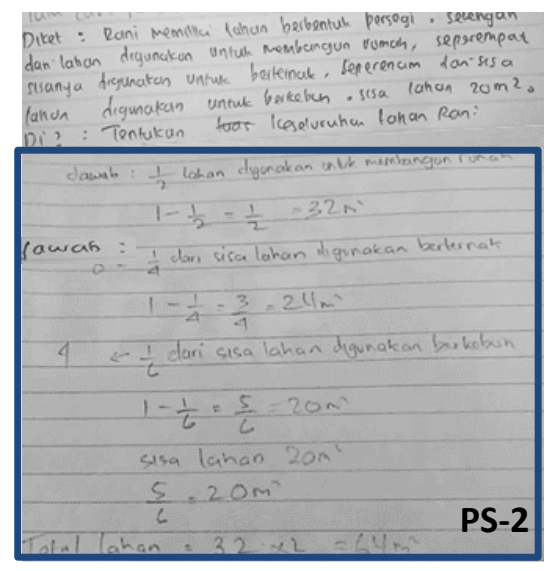

Gambar 7. Hasil pekerjaan SS nomor 2

Berikut hasil wawancara untuk menggali informasi lebih lanjut terhadap hasil pekerjaan SS.

Peneliti : Jelaskan bagaimana kamu dapat menentukan total lahannya adalah $64 m^{2}$ !

SSO3 : Karena dari yang diketahui yang pertama setangah digunakan untuk membangun rumah berarti sisa lahannya setengah. Lalu seperempat dari sisanya digunakan untuk berternak maka sisa lahannya itu tiga perempat. Seperenam dari sisa digunakan berkerbun berarti sisanya lima perenam. Karena sisa lahannya lima perenam ini sama dengan $20 \mathrm{~m}^{2}$. Maka seperenamnya berarti $4 \mathrm{~m}^{2}$. Total lahan berarti $24 \mathrm{~m}^{2} .3 / 4$ lahan itu sama dengan $24 \mathrm{~m}^{2}$. Maka 1/4 lahan itu $8 \mathrm{~m}^{2}$. Total lahan sekarang $32 \mathrm{~m}^{2} .32 \mathrm{~m}^{2}$ itu sama dengan sisa lahan setelah dibangun rumah. Karena sisa lahan untuk membangun rumah adalah 1/2 maka sama dengan $32 \mathrm{~m}^{2}$. Kemudian untuk total lahannya $32 \mathrm{~m}^{2}$ saya kalikan 2 maka totalnya $64 \mathrm{~m}^{2}$.

Peneliti : Mengapa kamu $32 \mathrm{~m}^{2}$ kamu kalikan dua. 
SS04 : Sebenarnya itu bu saya misalkan jika total tanahnya itu satu. Jika setengahnya digunakan untuk membangun rumah berarti sisa lahannya juga setengah. Jadi besarnya sama bu. Jika sisa lahannya $32 \mathrm{~m}^{2}$ maka luas tanah untuk membangun rumah juga $32 \mathrm{~m}^{2}$.

Berdasarkan hasil pekerjaan dan wawancara siswa pada nomor 2, SS mampu menulis kembali rumusan masalah menggunakan bahasa mereka sendiri, ini berarti SS telah memahami masalah. Kemudian SS mampu menyelesaikan permasalahan dimulai dengan hasil akhir, hal ini dibuktikan dengan SS memulai pekerjaan melalui sisa lahan (PS-2). SS juga mampu bergerak mundur untuk menentukan keadaan awal, dimana SS berjalan mundur hingga menemukan jika lahan yang digunakan untuk membangun rumah sama besar dengan sisa lahannya, dengan begitu maka akan ditemukan luas keseluruhan lahannya (SS06). Hal ini berarti SS telah memenuhi semua indikator strategi pemecahan masalah berjalan mundur. Kemudian pada pekerjaan nomor 3, SS menjawab permasalahan dengan benar dan memberikan penjelasan yang mendukung pekerjaannya

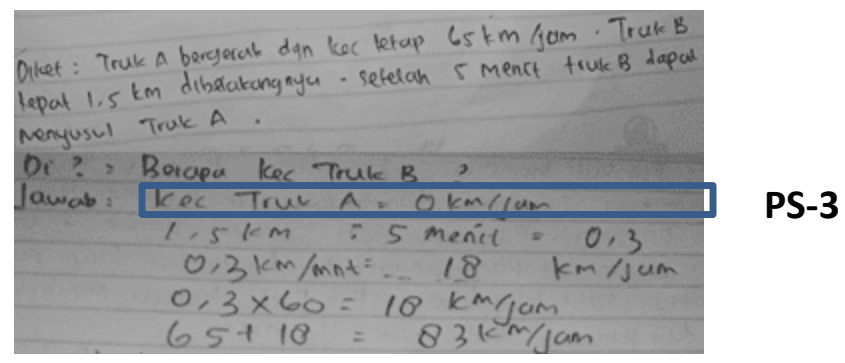

Gambar 8. Hasil pekerjaan SS nomor 3

Berikut hasil wawancara untuk menggali informasi lebih lanjut terhadap hasil pekerjaan SS.

Peneliti : Bagaimana kamu mengetahui jika kecepatan truk A adalah 0 km/jam?

SSO9 : Karena di soal diketahui jika truk A bergerak dengan kecepatan tetap bu jadi kecepatan truk A tersebut $0 \mathrm{~km} / \mathrm{jam}$.

Peneliti : Mengapa kamu menambahkan 65 dalam menentukan kecepatan truk B?

SS010 : Karena 18 km/jam itu maksudnya truk B 18km/jam lebih cepat dari truk A. Jadi nanti kecepatan truk $B$ adalah kecepatan truk A ditambah dengan 18 km/jam.

Bersadarkan hasil pekerjaan dan wawancara pada nomor 3, SS mampu menulis kembali rumusan masalah menggunakan bahasa mereka sendiri, ini berarti SS telah memahami masalah. Selanjutnya SS mampu mengasumsikan suatu maslaah dalam keadaan paling ekstrim dengan mengasumsikan jika truk A yang bergerak tetap maka kecepatan truk A menjadi 0 km/jam (PS-3 dan SS09). Dengan demikian, SS telah memenuhi indikator strategi pemecahan masalah menggunakan keadaan yang ekstrim dalam menyelesaikan masalah. Kemudian pada pekerjaan nomor 4, SS menjawab permasalahan dengan benar dan memberikan penjelasan yang mendukung pekerjaannya.

Berikut hasil wawancara untuk menggali informasi lebih lanjut terhadap hasil pekerjaan SS.

Peneliti : Bagaimana kamu memperoleh hasil jika angka pasangan Aldi adalah 15?

SS12 : Saya mencari angka yang jika ditambahkan dengan satu jumlahnya kuadarat. Kemudian saya cari pasangan-pasangan dari angka 3, 8, dan 15. Setelah itu saya mengeliminasi 
angka-angka tersebut. Dari kemungkinan itu saya mencoba-coba dan menyimpulkan jika angka dengan nilai kecil berpasangan dengan angka yang bernilai besar. Jadi pasangan dari 1 adalah 15

Peneliti : Bagaimana kamu dapat menyimpulkan bahwa angka yang bernilai kecil berpasangan dengan angka yang bernilai besar?

SS13 : Karena dari kemungkinan yang tertulis angka 8 hanya dapat berpasangan dengan 17, jadi saya menyimpulkan jika 1 berpasangan dengan 15 kemudian 3 dan 13.

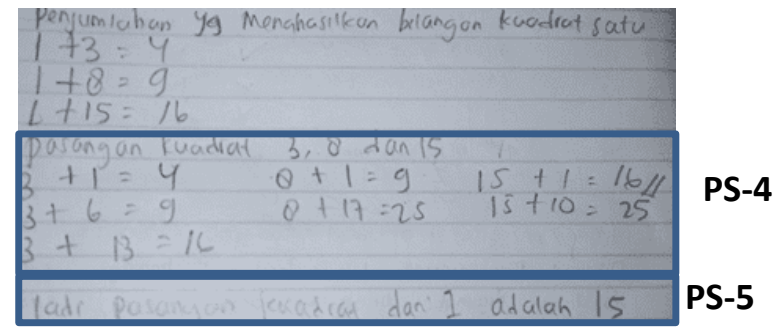

Gambar 9. Hasil pekerjaan SS nomor 4

Bersadarkan hasil pekerjaan dan wawancara pada nomor 3, SS telah memahami masalah. Hal tersebut ditunjukkan dengan SS mampu menulis kembali rumusan masalah menggunakan bahasa mereka sendiri. Kemudian SS mampu membuat semua kemungkinan jawaban dengan menuliskan kemungkinan pasangan satu adalah 3, 8, dan 15 (PS-4). Hal ini berarti SS telah memenuhi indikator strategi pemecahan masalah mempertimbangkan segala kemungkinan, dimana SS mampu menuliskan semua kemungkinan kemudian menenmukan jawaban yang benar. Kemudian SS juga memenuhi indikator strategi pemecahan maslah uji coba. Hal ini dibukitkan dengan SS mampu mengeleminasi pasangan dengan cara mencoba-coba (SS12 dan SS13). Pada tahap akhir SS juga menuliskan kesimpulan dari penyelesaiannya (PS-5).

\section{Siswa dengan Kemampuan Matematika Redah (SR)}

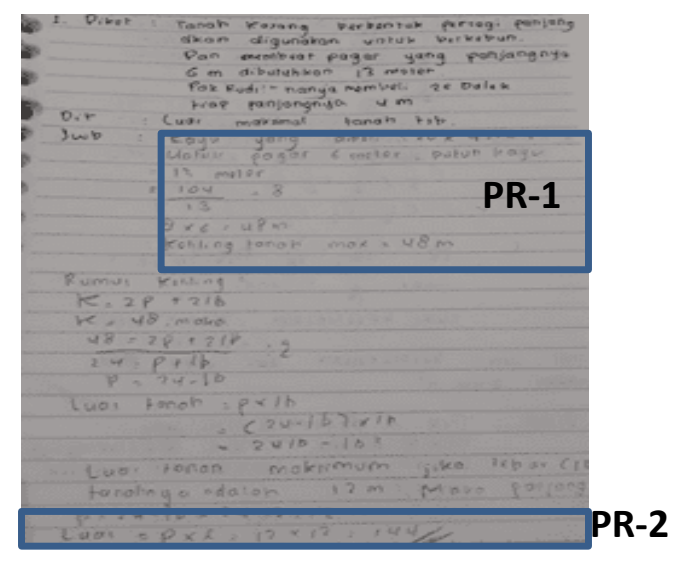

Gambar 10. Hasil pekerjaan SR nomor 1

Berikut hasil wawancara untuk menggali informasi lebih lanjut terhadap hasil pekerjaan SR.

Peneliti : Apakah kamu sudah memahami permasalahan tersebut?

SRO1 : Saya sedikit kebingungan bu dalam memahami maksud soal tersebut bu. 
Peneliti : Coba jelaskan bagaimana cara menentukan keliling sama dengan 48!

SRO2 : Saya mencari terlebih dahulu panjang keseluruhan balok kayu yaitu 104, kemudian di bagi

13 untuk menentukan banyak pagar yang terbentuk. Setelah diketahui banyak pagar maka di kalikan $6 m$ untuk mengukur panjang pagar keseluruhan. Jadi panjang pagar 8x6=48. Keliling sama dengan panjang pagar keseluruhan bu.

Peneliti : Mengapa panjang tanah sama dengan 12 menjadi luas maksimum?

SR03 : Karena saya mencoba- coba menemukan jika panjang dan lebarnya sama maka nanti luasnya maksimum $144 \mathrm{~m}^{2}$.

Peneliti : Bagaimana dengan panjang jika lebih dari 12 ?

SR04 : Saya sudah mencoba, jika pajangnya lebih dari 12 maka luasnya kurang dari $144 \mathrm{~m}^{2}$.

Bersadarkan hasil pekerjaan dan wawancara pada nomor 3, SR telah memahami masalah. Kemudian SR mampu menganalisis hubungan antara yang diketahui dan ditanyakan, dimana SR mencari panjang keseluruhan kayu terlebih dahulu (SR02). SR juga mampu menemukan informasi baru berdasarkan hasil analisis yaitu bayak pagar yang dapat dibuat dari panjang kayu tersebut (PR-1). Sehingga, SR memenuhi indikator strategi pemikiran logis. Selanjutnya dalam menentukan luas maksimum tanah, SR mencoba-coba dengan mengubah panjang dan lebarnya (PR-2, SR03). SR juga menuliskan kesimpulan bahwa luas lahan maksimal yaitu $144 \mathrm{~m}^{2}$ (PR - 2). Hal ini menunjukkan jika SR juga menggunakan indikator strategi pemecahan masalah uji coba.

Kemudian pada pekerjaan nomor 2, SR menjawab permasalahan dengan benar dan memberikan penjelasan yang mendukung pekerjaannya.

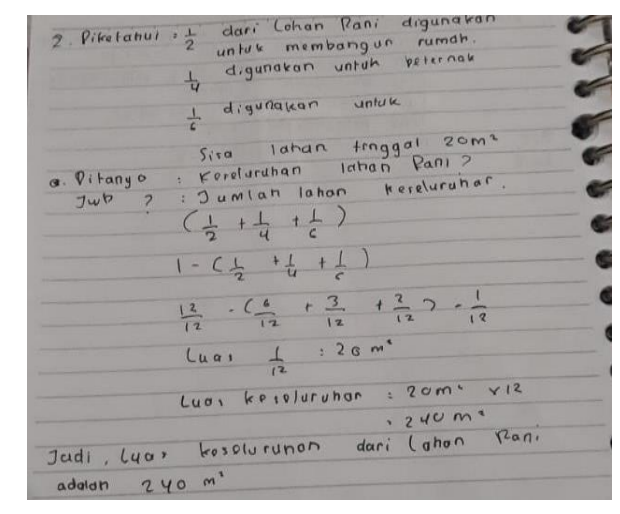

Gambar 11. Hasil pekerjaan SR nomor 2

Berikut hasil wawancara untuk menggali informasi lebih lanjut terhadap hasil pekerjaan SR.

Peneliti : Apakah kamu paham dengan permasalahan nomor dua?

SR06 : Jujur saya mengalami kesulitan dalam memahami soal nomor dua bu.

Peneliti : Sekarang coba kamu jelaskan bagaimana kamu memperoleh hasil $240 \mathrm{~m}^{2}$ ?

SR07 : Jadi apa yang diketahui dalam soal itu saya jumlahkan dulu bu,karena mencari total keseluruhan lahan yang digunakan maka diperoleh $\frac{11}{12}$. Jadi sisa lahan adalah $\frac{1}{12}$. 
Karena sisa lahan sama dengan $20 \mathrm{~m}^{2}$, maka luas lahan keseluruhan dikalikan 12 yaitu $240 m^{2}$.

Berdasarkan penyelesaian SR nomor dua, SR tidak menyelesaikan permasalah dengan benar. Hal ini disebabkan karena SR merasa kesulitan dalam memahami permasalahan. Tidak ada stretegi permasalahan yang digunakan SR dalam menyelesaikan permasalahan tersebut. Selanjutnya pada pekerjaan nomor 3, SR menjawab permasalahan dengan benar dan memberikan penjelasan yang mendukung pekerjaannya.

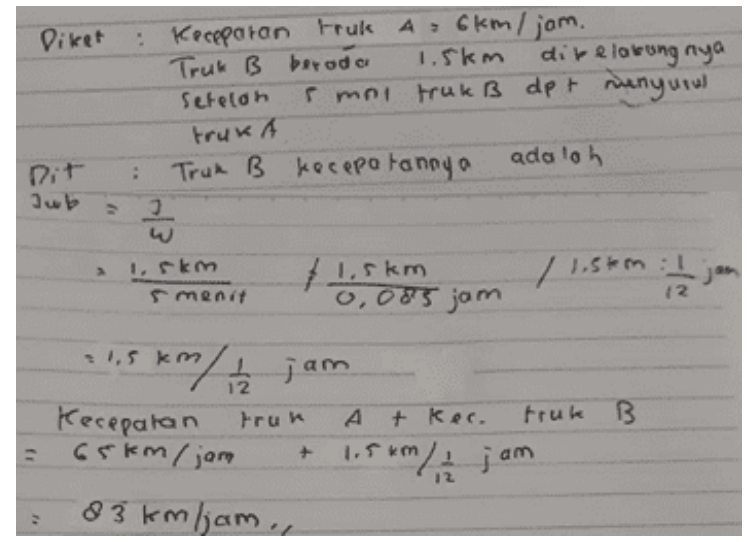

Gambar 12. Hasil jawaban siswa SR nomor 3

Berikut hasil wawancara untuk menggali informasi lebih lanjut terhadap hasil pekerjaan SR.

Peneliti : Apakah kamu sudah memahami permasalahan tersebut?

SR09 : Sudah bu.

Peneliti : Bagaimana menurutmu mengenai informasi bahwa truk A bergerak dengan kecepatan tetap $65 \mathrm{~km} / \mathrm{jam}$ ?

SR10 : Karena di soal diketahui jika kecepatan truk A tetap maka saya beranggapan bahwa truk itu berhenti agar truk B bisa menyusul, maka truk A kecepatannya 0 km/jam.

Peneliti : Kemudian apakah maksud dari kecepatan truk A ditambah kecepatan truk B?

SR11 : Awalnya saya mencari kecepatan truk B dalam waktu 5 menit yaitu 1,5 km / $\frac{1}{12} \mathrm{jam}$. Kemudian mencari kecepatan truk $B$ dengan menambahkan kecepatan truk $A$ dan kecepatan truk $B$ selang 5 menit.

Sedangkan pada pekerjaan siswa nomor 3, SR telah memahami masalah. Hal tersebut ditunjukkan dengan SR mampu menulis kembali rumusan masalah. kemudian SR mengasumsikan truk A yang bergerak tetap jadi kecepatan truk A adalah 0 km/jam (SR10). Hal ini berarti SR memenuhi indikaror strategi pemecahan masalah menggunkan keadaan yang ekstrim dalam menyelesaikan masalah, dimana SR mampu mengasumsikan atau memisalkan suatu masalah dalam keadaan paling ekstrim (jika perlu menggilangkan keadaan tersebut). Pada tahap akhir SR tidak menuliskan kesimpulan dari penyelesaian masalah.

Pada soal nomor 4 subjek SR tidak dapat menyelesaikannya karena waktu yang diberikan telah habis. Hal ini diperjelas dalam hasil wawancara berikut. 
Peneliti : Mengapa kamu tidak menyelesaiakan soal nomor 4?

SR13 : Karena saya kehabisan waktu bu, saat itu saya masih membaca soalnya.

Peneliti : Apakah kamu memahami maksud dari soalnya?

SR14 : Saya sebenarnya kurang mengerti bu, bingung bu. Saya sudah membaca dua kali tapi saya kurang mengerti dan saya kehabisan waktu bu.

Berdasarkan wawancara tersebut SR tidak dapat menggunakan strategi pemecahan masalah dalam menyelesaikannya. Hal ini didukung dengan SR kurang mampu memahami masalah yang diberikan.

\section{Diskusi}

Berdasarkan hasil penelitian di atas, strategi yang digunakan siswa ada yang berbeda dan ada yang sama. Siswa berkemampuan matematika tinggi mampu mengasumsikan suatu masalah pada keadaan paling ekstrim dan menemukan konsep baru yang lebih mudah untuk menyelesaikan masalah. Siswa berkemampuan tinggi juga mampu mengolah dan mengorganisir data dengan membuat daftar dan melakukan coba-coba. Hal ini selaras dengan pendapat Sidiq \& Choiri (2019) bahwa dengan mengorganisir data, maka data akan lebih mudah untuk dipahami mengenai apa yang terjadi. Selain itu siswa berkemampuan matematika tinggi mampu membuat kemungkinan jawaban dan memeriksa jawaban hingga ditemukan jawaban yang tepat. Sehingga berdasarkan penjelasan tersebut siswa dengan kemampuan matematika tinggi menggunakan beberapa strategi pemecahan masalah, yaitu penalaran logis, menggunakan keadaan yang ekstrim melakukan uji-coba, mengorganisir data, mengubah sudut pandang terhadap masalah, dan mempertimbangkan segala kemungkinan. Hal ini diperkuat oleh pendapat Purnamasari \& Setiawan (2019) yang menyatakan bahwa siswa yang memiliki kemampuan matematika tinggi memiliki kemampuan pemecahan masalah meliputi memahami masalah, menyusun strategi pemecahan, melaksanakan strategi yang telah dibuat dan memeriksa kembali hasil yang diperoleh yang lebih baik dibandingkan siswa yang memiliki kemampuan matematika sedang dan rendah.

Selanjunya, siswa berkemampuan matematika sedang dalam menyelesaikan masalah mampu memulai dengan hasil akhir kemudian bergerak mundur untuk menentukan keadaan awal dan melakukan coba-coba. Dalam hal ini, siswa berkemampuan sedang dapat mengasumsikan suatu masalah pada keadaan paling ekstrim dan membuat kemungkinan jawaban untuk menemukan jawaban yang benar kemudian membuat kesimpulan dengan benar. Sehingga berdasarkan penjelasan tersebut siswa yang memiliki kemampuan matematika sedang menggunakan beberapa strategi pemecahan masalah, yaitu menggunakan keadaan yang ekstrim melakukan uji-coba, berjalan mundur, dan mempertimbangkan segala kemungkinan. Hal diperkuat oleh pendapat Purnamasari \& Setiawan (2019) yang menyatakan bahwa siswa yang memiliki kemampuan matematika sedang memiliki kemampuan pemecahan masalah meliputi memahami masalah, menyusun strategi pemecahan, melaksanakan strategi yang telah dibuat dan memeriksa kembali hasil yang diperoleh yang lebih baik dibandingkan siswa yang memiliki kemampuan matematika rendah. 
Kemudian, siswa berkemampuan matematika rendah mampu mengasumsikan suatu masalah pada keadaan paling ekstrim dan melakukan coba-coba. Dalam memecahkan suau masalah siswa berkemampuan rendah dapat menganalisis hubungan antara yang diketahui dan ditanyakan sehingga mendapatkan informasi baru untuk menyelesaikannya. Selain itu siswa mampu mencoba satu-satu kemungkinan jawaban hingga ditemukan jawaban yang tepat. Sehingga berdasarkan penjelasan tersebut siswa yang memiliki kemampuan matematika rendah menggunakan beberapa strategi pemecahan masalah, yaitu menggunakan keadaan yang ekstrim, melakukan uji-coba, dan penalaran logis. Hal ini selaras dengan pendapat Kushendri dan Zanthy (2019) bahwa siswa yang memiliki kemampuan rendah, tidak memahami masalah dengan baik, sehingga pada saat melaksanakan strategi pemecahan masalah siswa belum maksiaml dalam melaksanakannya, sehingga paling sedikit menggunakan strategi pemecahan dibandingkan siswa berkemampuan tinggi dan sedang.

\section{KESIMPULAN}

Berdasarkan analisis strategi pemecahan masalah matematika siswa SMP ditinjau dari kemampuan matematika, hasil dan pembahasan yang telah dilakukan menunjukkan siswa yang memiliki kemampuan matematika tinggi dapat menggunakan 6 strategi pemecaha masalah dalam menyelesaikan masalah, yaitu pemikiran logis, uji-coba, mengubah cara pandang terhadap masalah, menggunakan keadaan ekstrim, mengorganisir data, dan mempertimbangkan segala kemungkinan. Sedangkan siswa yang memiliki kemampuan matematika sedang dapat menggunakan 4 strategi pemecaha masalah dalam menyelesaikan masalah, yaitu uji-coba, berjalan mundur, menggunakan keadaan ekstrim, dan mempertimbangkan segala kemungkinan. Serta siswa yang memiliki kemampuan matematika rendah dapat menggunakan 3 strategi pemecaha masalah dalam menyelesaikan masalah, yaitu pemikiran logis, uji-coba, dan menggunakan keadaan ekstrim.

Sebaiknya guru dalam pembelajaran rutin menggunakan soal yang mengacu pada pemecahan masalah agar siswa dapat membiasakan diri dengan pemecahan masalah matematika. Dengan seiring siswa terbiasa dengan pemecahan masalah, siswa akan dapat menerapkan strategi pemecahan masalah dengan benar. Bagi penelitian selanjutnya yang akan melakukan penelitian tentang strategi pemecahan masalah untuk melakukan kajian penilaian misalkan ditinjau dari gender atau kecenderungan kepribadian siswa.

\section{UCAPAN TERIMA KASIH}

Terimakasih kepada Bapak/Ibu dosen yang sudah membimbing selama ini. Terimakasih kepada Bapak Kepala Sekolah, Guru, dan siswa di SMP Negeri 1 Grogol yang sudah memberikan izin, dan membantu penulis dalam pelaksanaan penelitian.

\section{REFERENSI}

Afgani, J. (2011). Materi pokok Analisis Kurikulum Matematika. Universitas Terbuka.

Andinasari, Zulkardi, Somakim, \& Wasiran, Y. (2019). Learning design of reciprocal proportionality 
using airplanes contex. Journal of Physics: Conference Series, 1166(1). https://doi.org/10.1088/1742-6596/1166/1/012018

Asmiati. (2014). Strategi siswa dalam memecahkan masalah matematika konstektual ditinjau dari gaya kognitif. Universitas Negeri Surabaya.

Aydogdu, M. Z., \& Kesan, C. (2014). A Research on Geometry Problem Solving Strategies Used by Elementary Mathematics Teacher Candidates. Journal of Educational and Instructional Studies in the World, 4(1), 53-62.

Ayuningrum, D. (2017). Strategi Pemecahan Masalah Matematika Siswa SMP Ditinjau Dari Tingkat Berpikir Geometri Van Hiele. Kreano, Jurnal Matematika Kreatif-Inovatif, 8(1), 27-34. https://doi.org/10.15294/kreano.v8i1.6851

Dahlan, J.A. (2011). Materi Pokok Analisis Kurikulum Matematika. Universitas Terbuka Jakarta.

Dinata, K. B. (2017). Strategi Pemecahan Masalah dalam Matematika. Jurnal Eksponen, 7, 56-57.

Effendi, L. A. (2012). Pembelajaran Matematika dengan Metode Penemuan Terbimbing untuk Meningkatkan Kemampuan Representasi dan Pemecahan Masalah Matematika Siswa SMP. Jurnal Penelitian Pendidikan UPI, 2,3.

Herlambang. (2013). Analisis Kemampuan Pemecahan Masalah Matematika Siswa Kelas VII-A SMP Negeri 1 Kepahiang Tentang Bangun Datar Ditinjau Dari Teori Van Hiele. Universitas Bengkulu.

Kushendri, \& Zanthy, L. S. (2019). Analisis Kemampuan Pemecahan Masalah Matematis Siswa SMA. Journal On Education, 1, 7.

Nurman, T. A. (2008). Perangkat Pembelajaran Matematika dengan Open-Ended Problem untuk Topik Fungsi di Kelas XIII IPA Sekolah Menengah Atas. Universitas Negeri Surabaya.

Posamentier, A. S., \& Krulik, S. (2008). Problem-Solving Strategies for Efficient and Elegant Solutions, Grades 6-12: A Resource for the Mathematics Teacher (SECOND EDI). Corwin Publishers.

Purnamasari, I., \& Setiawan, W. (2019). Analisis Kemampuan Pemecahan Masalah Matematis Siswa SMP pada Materi SPLDV Ditinjau dari Kemampuan Awal Matematika. Journal of Medives : Journal of Mathematics Education IKIP Veteran Semarang, 3(2), 207. https://doi.org/10.31331/medivesveteran.v3i2.771.

Salido, A. \& Dasari, D. (2019). The Analysis of Students' Reflective Thinking Ability Viewed by Students' Mathematical Ability at Senior High School. Journal of Physics : conference series, 1157(2).https://doi.org/10.1088/1742-6596/1157/2/022121.

Shidiq, U., \& Choiri, M. (2019). Metode Penelitian Kualitatif di Bidang Pendidikan. In Journal of Chemical Information and Modeling (Vol. 53, Issue 9).

Sugiyono. (2019). Metode Penelitian Kuantitatif Kualitatif dan $R \& D$ (1st ed.). Alfabeta.

Suyanto. (2013). Problematika Kesiapan SDM Indonesia Menyongsong Implementasi ASEAN Free Trade Area (AFTA) 2015. Universitas Negeri Yogyakarta. http://fe.uny.ac.id/id/berita/kesiapansdm-indonesia-menghadapi-afta-2015

Winarni, E. S. \& Harmini, S. (2017). Matematika untuk PGSD. PT Remaja Rosdakarya. 